\title{
Impact of Early Lactation Somatic Cell Count in Heifers on Milk Yield Over the First Lactation
}

\author{
S. De Vliegher, ${ }^{1}$ H. W. Barkema, ${ }^{2}$ H. Stryhn, ${ }^{2}$ G. Opsomer, ${ }^{1}$ and A. de Kruif ${ }^{1}$ \\ ${ }^{1}$ Department of Reproduction, Obstetrics, and Herd Health, Faculty of Veterinary Medicine, \\ Ghent University, Merelbeke, Belgium \\ ${ }^{2}$ Department of Health Management, Atlantic Veterinary College, \\ University of Prince Edward Island, Charlottetown, Canada
}

\begin{abstract}
The objective of this study was to estimate the impact of somatic cell count (SCC) in early lactation (SCCel) [measured between 5 to $14 \mathrm{~d}$ in milk (DIM)] of dairy heifers on test-day milk yield (MY) during the first lactation.

In total, 117,496 four-weekly test-day records of 14,243 heifers were used. A multilevel regression analysis, which included test-day SCC among the explanatory variables, revealed that an increase by one unit of the natural log-transformed SCCel (LnSCCel) was on average associated with a decrease in MY of $0.13 \mathrm{~kg} / \mathrm{d}$ later in lactation. As an example, a heifer with an SCCel of 50,000 cells $/ \mathrm{mL}$ measured at $10 \mathrm{DIM}$ was estimated to produce 119 and $155 \mathrm{~kg}$ more milk during its first lactation than heifers with a SCCel of 500,000 and $1,000,000$ cells $/ \mathrm{mL}$, respectively. When not accounting for test-day SCC, the effect of LnSCCel on MY was larger, indicating that part of the negative impact of elevated SCCel was associated with elevated test-day SCC later in lactation.

Furthermore, an elevated SCCel at 14 DIM had a larger impact than an equally elevated SCCel measured at an earlier DIM. In addition, the negative effect of an elevated SCCel remained present during almost the entire first lactation in a subgroup of heifers with a second test-day $\mathrm{SCC} \leq 50,000$ cells $/ \mathrm{mL}$, suggesting that prevention rather than cure of an elevated SCCel should be preferred.

This study stresses the importance of heifers having low SCCel, as an elevated SCCel will negatively affect milk production during the first lactation, probably via impairment of mammary function and, to a smaller extent, via elevated test-day SCC later in lactation.
\end{abstract}

(Key words: dairy heifer, early lactation, milk yield, somatic cell count)

Received July 27, 2004.

Accepted November 3, 2004.

Corresponding author: Sarne De Vliegher; e-mail: Sarne. Devliegher@UGent.be.
Abbreviation key: LnSCC = natural log-transformed SCC, LnSCCel = natural log-transformed SCCel, $\mathbf{M Y}=$ milk yield at test-day $(\mathrm{kg}), \mathbf{S C C e l}=\mathrm{SCC}$ in early lactation (between 5 and 14 DIM).

\section{INTRODUCTION}

Heifer mastitis is a well-known problem. Many studies have reported a high prevalence of IMI in heifers around calving (Oliver and Mitchell, 1983; Pankey et al., 1991; Oliver et al., 1992; Roberson et al., 1994; Myllys, 1995; Aarestrup and Jensen, 1997; Oliver et al., 2003). More than $27 \%$ of 14,766 Belgian dairy heifers had an SCC in early lactation (SCCel) $>200,000$ cells/mL, suggesting they had an IMI during the peripartum period (De Vliegher et al., 2004a). Coagulasenegative staphylococci are responsible for the majority of the IMI in nonlactating and freshly calved heifers, but Staphylococcus aureus and environmental pathogens may also play a role (Oliver and Mitchell, 1983; Pankey et al., 1991; Oliver et al., 1992; Roberson et al., 1994; Myllys, 1995; Aarestrup and Jensen, 1997; Oliver et al., 2003).

Intramammary infection at parturition, particularly when caused by a major pathogen, will result in an increased SCC at that moment (Barkema et al., 1999). Heifers with an elevated SCCel on average have elevated test-day SCC, are more at risk for having testday SCC >200,000 cells/mL (De Vliegher et al., 2004a), and have an increased probability of clinical mastitis (Rupp and Boichard, 2000). Future milk production can be compromised as well (Oliver and Jayarao, 1997).

The negative association between test-day SCC and milk yield has been addressed in some recent studies: the individual milk yield loss in heifers has been estimated at $1.29 \mathrm{~kg} / \mathrm{d}$ for each unit increase in the $\log _{10}$ SCC (Koldeweij et al., 1999). In lactating heifers without clinical mastitis, the reduction in milk yield was $0.30,0.61$, and $1.09 \mathrm{~kg}$ when SCC was $100,000,200,000$, and 600,000 cells/mL, respectively (Hortet et al., 1999). In organic dairy herds, heifers had a production loss of $0.20 \mathrm{~kg} / \mathrm{d}$ of energy-corrected milk with each 2 -fold 
Table 1. Descriptive statistics of milk yield $(\mathrm{kg} / \mathrm{d})$ throughout the first lactation.

\begin{tabular}{|c|c|c|c|c|c|c|}
\hline Dataset & & $\mathrm{n}$ & Average & $\mathrm{SD}$ & Min & Max \\
\hline \multirow[t]{11}{*}{ Full $^{1}$} & Test-season & & & & & \\
\hline & January-March & 28,871 & 23.2 & 5.3 & 1.3 & 47.2 \\
\hline & April-June & 37,039 & 22.9 & 5.2 & 0.9 & 45.4 \\
\hline & July-September & 22,504 & 21.9 & 5.1 & 1.3 & 43.5 \\
\hline & October-December & 29,082 & 22.3 & 5.1 & 1.2 & 44.6 \\
\hline & Breed & & & & & \\
\hline & Belgian White-Blue and unknown breed & 11,175 & 19.3 & 6.8 & 0.9 & 47.2 \\
\hline & MRY, ${ }^{2}$ Red, Red and White, and Jersey & 11,682 & 19.6 & 4.3 & 5.8 & 40.7 \\
\hline & Red Holstein-Friesian & 32,890 & 21.9 & 4.4 & 6.7 & 42.8 \\
\hline & Black Holstein-Friesian & 61,749 & 24.3 & 4.8 & 5.2 & 47.0 \\
\hline & Total & 117,496 & 22.7 & 5.2 & 0.9 & 47.2 \\
\hline \multirow[t]{11}{*}{$\mathrm{Sub}^{3}$} & Test-season & & & & & \\
\hline & January-March & 16,258 & 23.7 & 5.1 & 1.8 & 47.0 \\
\hline & April-June & 20,808 & 23.3 & 5.0 & 1.4 & 45.1 \\
\hline & July-September & 12,422 & 22.4 & 4.8 & 1.7 & 41.4 \\
\hline & October-December & 15,970 & 22.8 & 4.9 & 1.6 & 44.6 \\
\hline & Breed & & & & & \\
\hline & Belgian White-Blue and unknown breed & 5595 & 20.3 & 5.9 & 1.4 & 40.0 \\
\hline & MRY, Red, Red and White, and Jersey & 6230 & 19.8 & 4.2 & 6.9 & 40.7 \\
\hline & Red Holstein-Friesian & 18,156 & 22.2 & 4.3 & 6.9 & 40.9 \\
\hline & Black Holstein-Friesian & 35,477 & 24.6 & 4.7 & 9.3 & 47.0 \\
\hline & Total & 65,458 & 23.1 & 5.0 & 1.4 & 47.0 \\
\hline
\end{tabular}

${ }^{1}$ Milk yield between 15 and 365 DIM from 14,234 heifers (full dataset).

${ }^{2} \mathrm{MRY}=$ Meuse-Rhine-Yssel.

${ }^{3}$ Milk yield between 15 and 365 DIM from 7807 heifers with a second test-day $\mathrm{SCC} \leq 50,000$ cells $/ \mathrm{mL}$ (subset of data).

increase in SCC between 100,000 and 1,500,000 cells/ $\mathrm{mL}$ (Bennedsgaard et al., 2003). The association between first test-day SCC and SCC later in lactation was investigated by Coffey et al. (1986): heifers with a first test-day SCC $<100,000,100,000$ to 400,000 , and $>400,000$ cells $/ \mathrm{mL}$ produced 6452,6050 , and $5696 \mathrm{~kg}$ during first lactation, respectively. Kirk et al. (1996), on the other hand, found that IMI with minor pathogens in heifers had no effect on average milk production during early to middle lactation. However, only one herd was included in that study.

The primary objective of the present study was to estimate the impact of SCCel on milk yield in the first lactation using multilevel regression analysis, taking into account the day of assessment of SCCel. The study accompanies a previous study (De Vliegher et al., 2004a) on the impact of SCCel on test-day SCC in the first lactation, based on the same data set. The present analysis extends that analysis by focusing on milk yield, and by investigating both the direct and indirect effects of elevated SCCel, while accounting for the hierarchical structure of the data.

\section{MATERIALS AND METHODS}

\section{Initial Data Set and Data Handling}

The data used in this study are described elsewhere (De Vliegher et al., 2004a). In short, approximately monthly milk recordings ( $\geq 5$ DIM) from 2000 and 2001 of all heifers of all Flemish (Belgium) dairy herds enrolled in the DHI program (Flemish Cattle Breeding Association, Oosterzele, Belgium) were used, including: SCC and milk yield on test-day (MY) (kg of milk), breed, DIM, and date of measurement.

Heifers were included if their first test-day in 2000 occurred between 5 and 14 DIM. In total, 117,496 testday records (full data set) from the first lactation (measured after 14 DIM) were available from 14,234 heifers belonging to 3264 herds. A subset of data was created by selecting heifers with a second test-day SCC (measured after 14 and before $75 \mathrm{DIM}) \leq 50,000$ cells $/ \mathrm{mL}$, resulting in 65,458 test-day records from 7807 heifers on 2827 herds.

\section{Statistical Analyses}

The statistical analyses aimed at quantifying the effect of SCC in early lactation (measured between 5 and 14 DIM) on MY during the first lactation. A natural logarithmic transformation of SCC (LnSCC) and SCCel (LnSCCel) was used (De Vliegher et al., 2004a).

For analysis of the repeated measurements of each heifer, both the full and subset of data were split into 12 subsets referred to as " $30-d$ DIM intervals" (15 to 45,46 to 75,76 to $105 \ldots$ DIM), reflecting the monthly milk recordings. These intervals were analyzed sepa- 


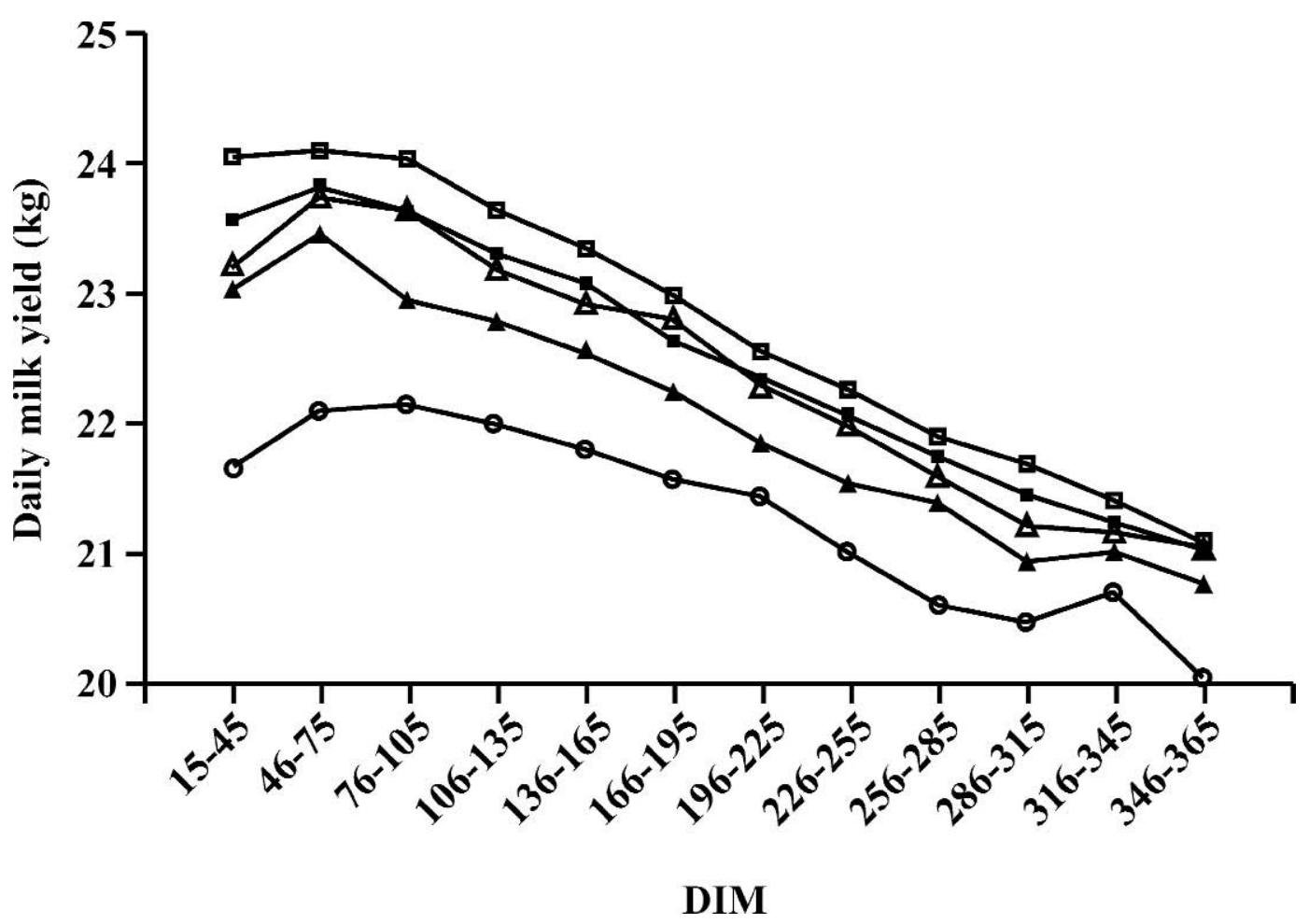

Figure 1. Average milk yield (kg/d) during first lactation from 14,234 (full data set) dairy heifers, stratified by SCC in early lactation (SCCel, $\times 1000$ cells $/ \mathrm{mL}$ ), 0 to $50(\square), 51$ to $200(\square), 201$ to $500(\triangle), 501$ to $1000(\boldsymbol{\Delta})$, and $>1000$ cells $/ \mathrm{mL}(\bigcirc)$.

rately, except that no analysis was performed for the first two 30-d DIM intervals from the subset of data because selection of animals was based on the measurements within those 2 intervals. To account for multiple testing of the same hypotheses in the 30-d DIM intervals, all $P$ values were multiplied by the number of intervals analyzed [Bonferroni correction, see De Vliegher et al. (2004a) for discussion and justification of the analytical approach].

Multilevel linear regression models (one model per 30-d DIM interval) were used to analyze MY as the outcome variable. The models included random effects for herds and heifers, the latter to account for a small number of heifers with 2 test recordings within the same 30-d interval [except for the first (15 to 45 DIM) and 12th (345 to 365 DIM) intervals]. All random effects and error terms were assumed normally distributed. The full model included regression terms for LnSCCel (predictor of main interest), DIM (between 5 and 14, the day of assessment of LnSCCel), and the categorical variables test-season and breed (4 levels each, as listed in Table 1). Moreover, the model included interaction terms between LnSCCel and the predictors DIM and breed, as well as a quadratic term for LnSCCel and its interaction with DIM. All models were fitted with and without LnSCC as predictor, which allowed studying changes in the estimate of LnSCCel when including LnSCC in the model, and helped to estimate the direct and indirect effects of LnSCCel. The continuous predictors were centered by subtracting their overall mean. After the assumptions of the full model had been evaluated using the residuals, the interaction terms were tested and were removed when nonsignificant (likelihood-ratio test). To facilitate comparison of models for different 30-d DIM intervals, a main effect was kept in all models as soon as it was significant in one 30-d DIM interval.

The distribution of variance of MY at the hierarchical levels (test, heifer, and herd) was assessed for the nullmodels (without fixed effects). The proportion of variation explained by the fixed effects was calculated as one minus the ratio of the total variance of the final model and the total variance of the null model (Snijders and Bosker, 1999).

Predicted cumulative production between 15 and 365 DIM was calculated for Black-Holstein heifers by multiplying the daily average predicted MY per 30-d DIM interval with 30 (20 for the last interval) and summing up these values over all 30-d DIM intervals. An average test-season effect was assumed.

All analyses were carried out using the MLwiN software, version 1.2 (Rasbash et al., 2000). The significance level for all analyses was set at $P \leq 0.05$. 
Table 2. Final multilevel linear regression models per 30-d DIM intervals describing milk yield (kg/d) during first lactation (between 15 and 365 DIM) in 2000 and 2001 from 14,234 dairy heifers from 3264 herds, accounting for log-transformed test-day SCC (full dataset).

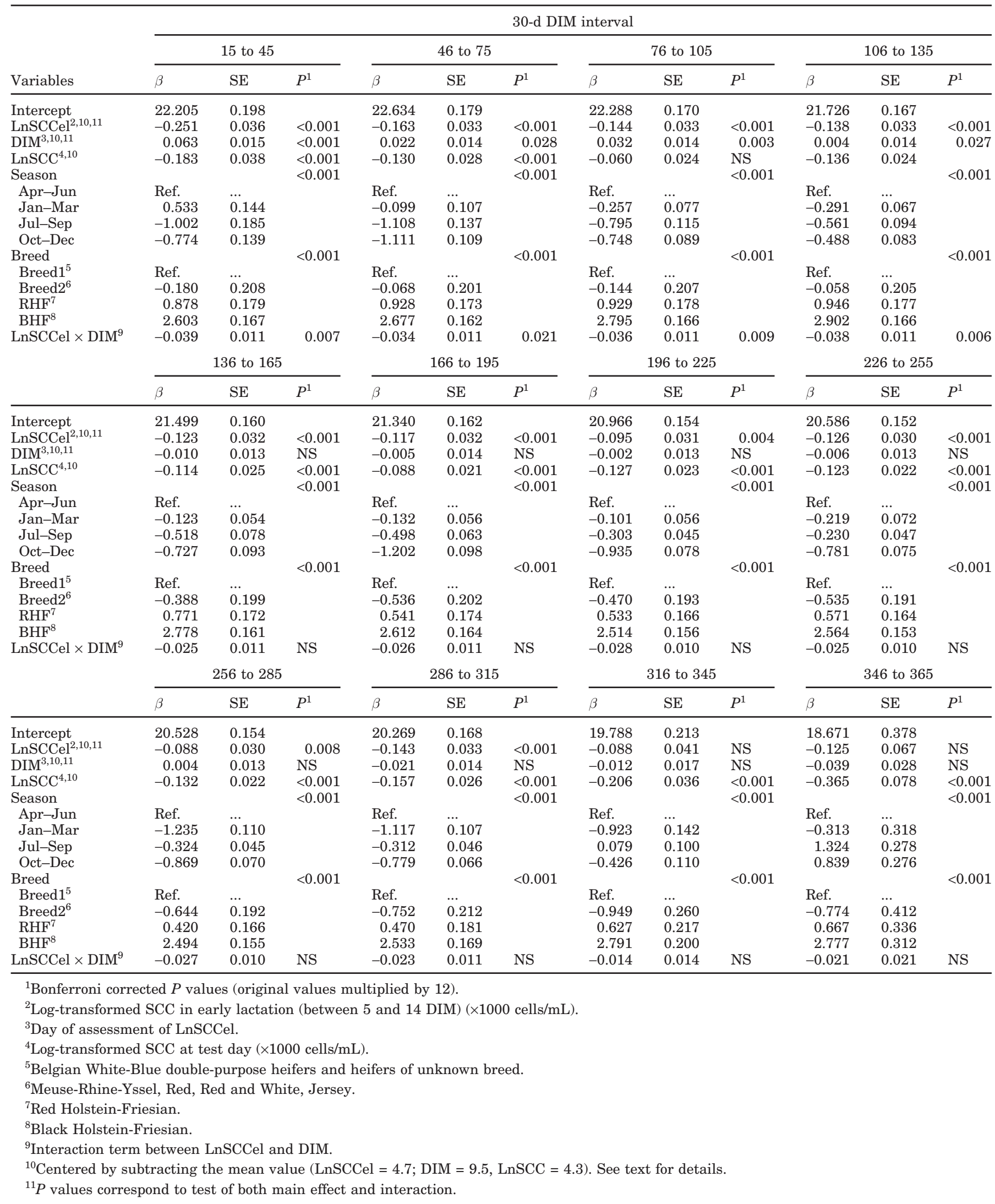




\section{RESULTS}

\section{Descriptive Analysis of SCCel and MY}

Geometric mean SCCel of the 14,234 selected heifers was 112,000 cells $/ \mathrm{mL}$, ranging from 5000 to $25,000,000$ cells/mL. More descriptive statistics on SCCel are presented elsewhere (De Vliegher et al., 2004a).

Average MY between 15 and 365 DIM was $22.7 \mathrm{~kg} /$ $\mathrm{d}$, ranging from 0.9 to $47.2 \mathrm{~kg} / \mathrm{d}$ (Table 1). The interquartile range was $6.7 \mathrm{~kg}$. Black Holstein-Friesians had the highest and the Belgian White Blue dual-purpose heifers and heifers of unknown breed had the lowest milk production. Small differences were present between test-seasons (Table 1). Average MY was $23.5 \mathrm{~kg} /$ $\mathrm{d}$ in the 15 to 4530 -d DIM interval, and increased to $23.8 \mathrm{~kg} / \mathrm{d}$ in the 46 to 75 interval, after which MY gradually decreased to $21 \mathrm{~kg} / \mathrm{d}$ at the end of the lactation (345 to 365 DIM).

Of the 14,234 heifers, $55 \%$ had a second test-day SCC $\leq 50,000$ cells $/ \mathrm{mL}$ and the 7807 heifers within this sub data set had an average MY $0.4 \mathrm{~kg}$ higher than all heifers (Table 1). Table 1 also shows differences between breeds and test-seasons.

\section{Effect of SCCel on Test-Day MY}

Milk yield stratified by 5 SCCel-classes is presented in Figure 1. Heifers having an SCCel $\leq 50,000$ cells/ $\mathrm{mL}$ produced on average $0.26 \mathrm{~kg} / \mathrm{d}$ more during the subsequent test-days compared with heifers starting their first lactation with a SCCel between 51,000 and 200,000 cells $/ \mathrm{mL}$. This difference was on average 1.44 $\mathrm{kg} / \mathrm{d}$ for heifers in the lowest SCCel class when compared with heifers with an SCCel $>1,000,000$ cells $/ \mathrm{mL}$. In general, differences between SCCel classes became smaller toward the end of the lactation.

Regression coefficients of LnSCCel on MY corrected for DIM, breed, season, and LnSCC are presented in Table 2. On average, if LnSCCel of a heifer was one unit higher than for another heifer, MY was $0.25,0.16$, and $0.14 \mathrm{~kg} / \mathrm{d}$ lower in the first, second, and third 30$\mathrm{d}$ DIM intervals, respectively. This interpretation assumes LnSCCel of the 2 heifers to be measured at the same, theoretical DIM of 9.5 (mean value between 5 and 14). The size of the effect decreased throughout the lactation (smaller impact in the later 30-d DIM intervals). Furthermore, the interaction between LnSCCel and DIM was significant in some of the 30-d DIM intervals, indicating that the impact of LnSCCel on MY depended on when it was measured in early lactation. As an example, for a recording at DIM 12, the effect in the first 30-d DIM interval would be $-0.251+$ $[-0.039 \times(12-9.5)]=-0.35 \mathrm{~kg} / \mathrm{d}$, whereas if the recording took place at DIM 7 , the effect would be -0.15 $\mathrm{kg} / \mathrm{d}$. This LnSCCel effect throughout the whole lactation comparing heifers differing by one unit calculated at 7, 9.5, and 12 DIM is illustrated in Figure 2. The impact of an elevated LnSCCel measured at 12 DIM was higher than that of an equally elevated LnSCCel at 7 DIM. Predicting the cumulative milk production of heifers with different SCCel values $(50,000,200,000$, 500,000 , and 1,000,000 cells $/ \mathrm{mL}$ ) measured between 5 and $14 \mathrm{DIM}$ also demonstrated this (Figure 3). A higher SCCel was always associated with lower production, but the predicted differences were smaller for heifers with different SCCel values measured at DIM 5 compared with heifers with different SCCel values recorded at a later DIM.

Test-day MY was significantly associated with season and breed. Black-Holstein heifers out-produced the other breeds (Table 2). The effect of LnSCCel on MY did not differ between breeds, as the interaction term between LnSCCel and breed was never significant.

Fitting models that did not include LnSCC as predictor variable resulted in larger estimates of LnSCCel. On average, if LnSCCel of one heifer was one unit higher than for another heifer, MY was $0.32,0.20$, and $0.16 \mathrm{~kg} / \mathrm{d}$ lower in the first, second, and third 30-d DIM intervals, respectively. As before, this interpretation assumes LnSCCel of the 2 heifers to be measured at the same, theoretical DIM of 9.5. The model-based estimates for LnSCCel (not correcting for LnSCC) in all 30-d DIM intervals are presented in Figure 2. The estimates of all other predictor variables are not presented because the changes were minimal.

Heifers with a second test-day SCC of $\leq 50,000$ cells/ $\mathrm{mL}$ (data subset, Figure 4) had higher test-day MY compared with heifers in the full data set (Figure 1), and the differences between heifers in different SCCel classes were smaller (Figures 1 and 3), corresponding to smaller regression coefficients of LnSCCel on MY (Table 3, left columns). However, the effect of LnSCCel (at DIM 9.5) was reasonably constant at $-0.1 \mathrm{~kg} / \mathrm{d}$ and significant until 255 DIM. As before, fitting models without LnSCC as a predictor variable resulted in larger LnSCCel estimates (Table 3, right columns).

Approximately 55 and $44 \%$ of the variation in MY resided at the herd and heifer level, respectively, with a very small proportion left at the test level. Between 10.3 (46 to 75 DIM) and $16.2 \%$ (316 to 345 DIM) of the variation was explained by adding the fixed effects.

In some 30-d DIM intervals, the quadratic term of LnSCCel was significant, indicating that (at least in those intervals) the association between MY and LnSCCel was nonlinear. We decided however, to present only models without the quadratic term, making interpretation of the models more straightforward. This approach was also preferred in an earlier study (De 


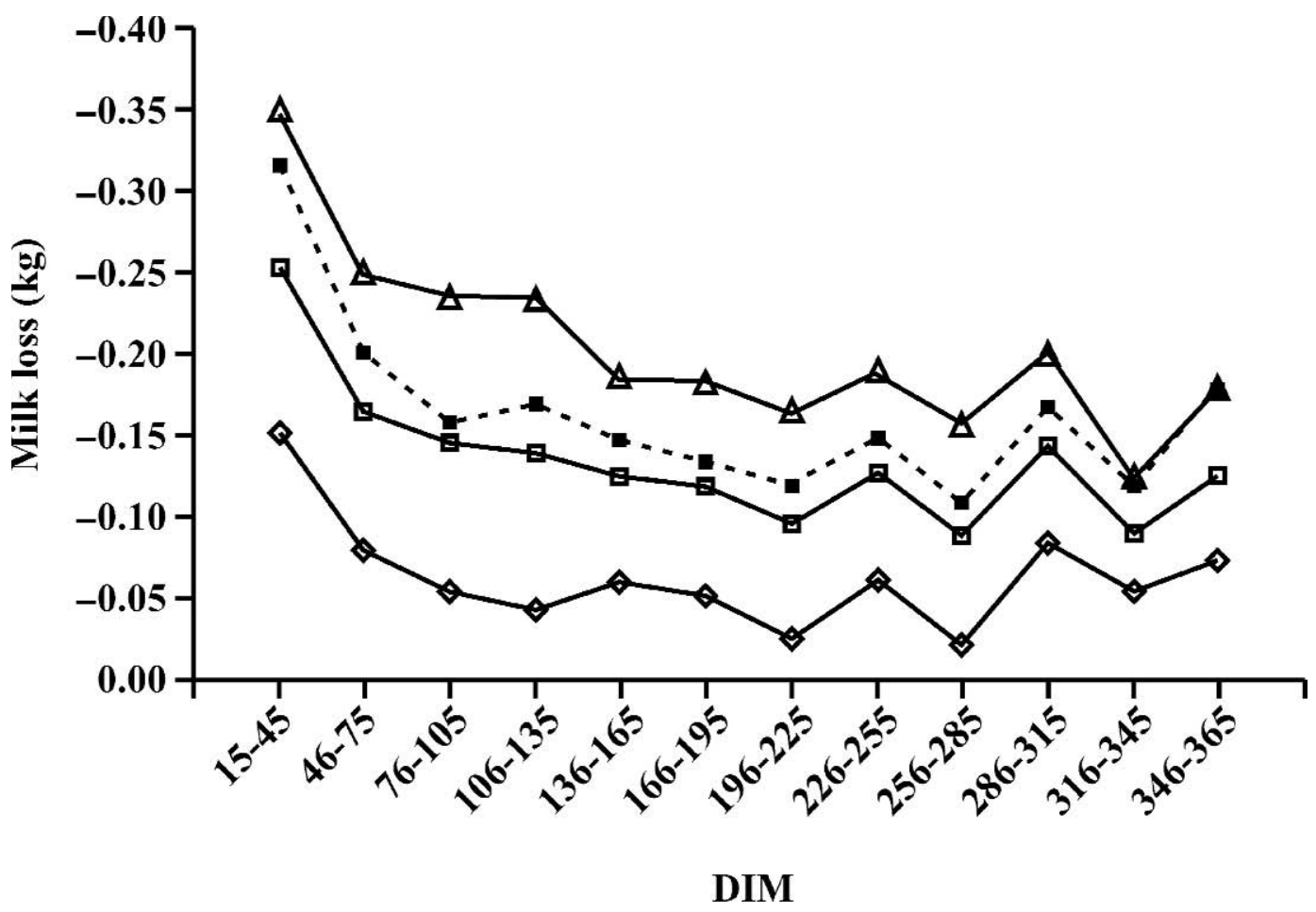

Figure 2. Regression coefficients for log-transformed SCC in early lactation (LnSCCel, $\times 1000$ cells/mL) per 30-d DIM interval measured at $7(\diamond), 9.5(\square)$, and $12(\triangle)$ DIM. Estimates are based on the final multilevel linear regression models describing milk yield $(\mathrm{kg} / \mathrm{d}) \mathrm{during}$ first lactation (between 15 and 365 DIM) in 2000 and 2001 from 14,234 dairy heifers from 3264 herds, accounting for log-transformed testday SCC (LnSCC, $\times 1000$ cells/mL). Regression coefficients for LnSCCel $(\times 1000$ cells $/ \mathrm{mL})$ per 30-d DIM interval measured at 9.5, but based on the final multilevel linear regression models not accounting for log-transformed test-day SCC $(\times 1000$ cells $/ \mathrm{mL})$ are indicated by the dashed line $(\boldsymbol{\square})$

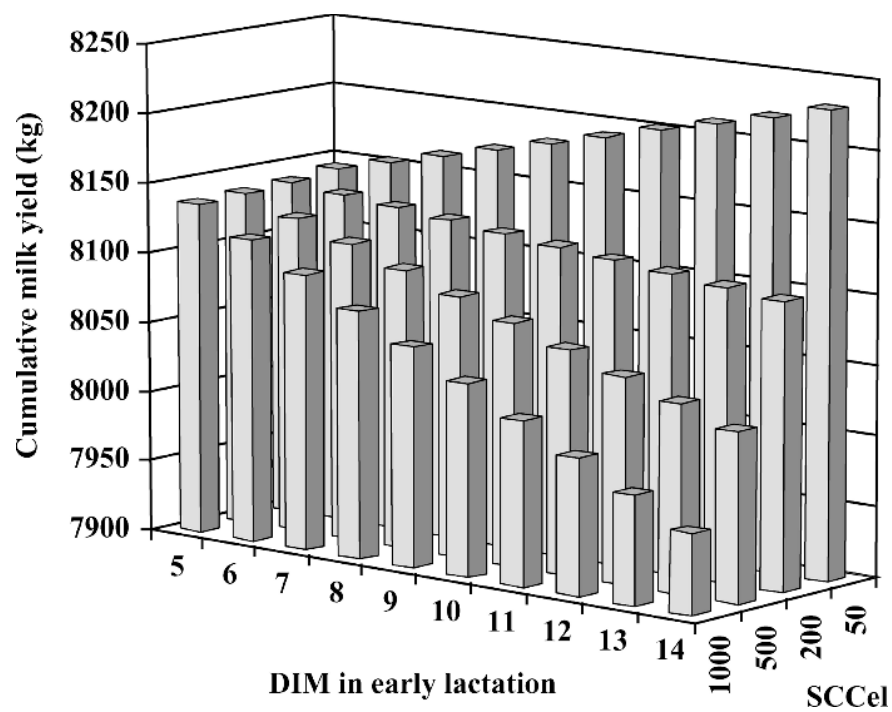

Figure 3. Estimated cumulative milk production between 15 and 365 DIM from Black-Holstein heifers with different SCC in early lactation $(\times 1000$ cells $/ \mathrm{mL})$ measured at different DIM, based on the final models accounting for log-transformed test-day SCC.
Vliegher et al., 2004a) and was based on inspection of graphs presenting the linear and nonlinear relation showing a good agreement.

\section{DISCUSSION}

Monthly milk-recording data were used to investigate the impact of SCCel, measured in the first 2 wk after calving, on MY in the subsequent first lactation. The day on which SCCel was assessed was taken into account. Elevated SCCel was associated with a reduced MY and a lower cumulative milk production during the first lactation, resulting in suboptimal revenues for the farmer.

Prevalence of IMI is high in peripartum dairy heifers (Oliver and Mitchell, 1983; Pankey et al., 1991; Oliver et al., 1992; Roberson et al., 1994; Myllys, 1995; Aarestrup and Jensen, 1997; Oliver et al., 2003). Coagulase-negative staphylococci are the predominant organisms causing these IMI, but the number of CNS infections decreases markedly in early lactation (Oliver and Mitchell, 1983; Matthews et al., 1992; Myllys, 1995; Kirk et al., 1996; Barkema et al., 1999), suggesting that most 


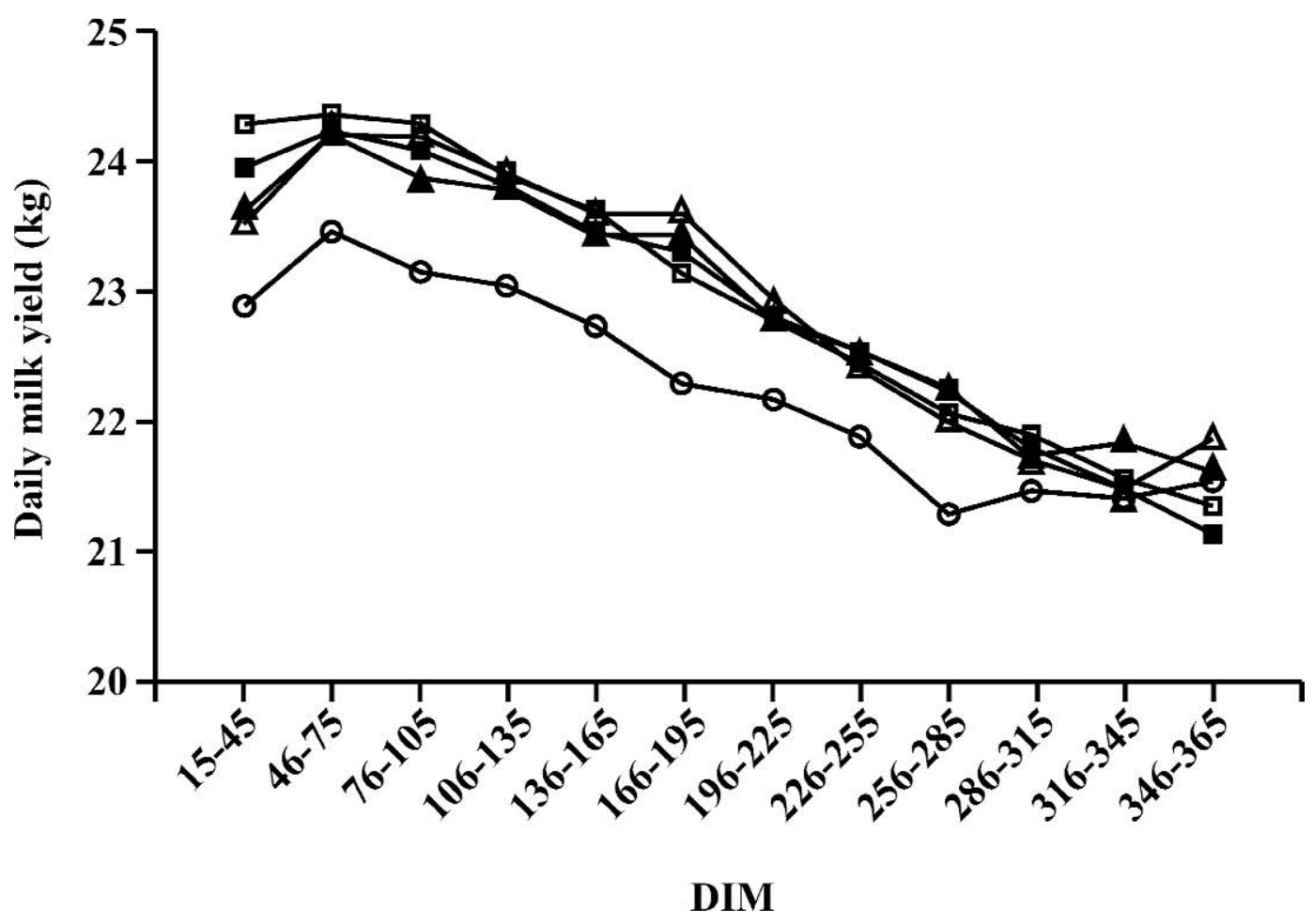

Figure 4. Average milk yield ( $\mathrm{kg} / \mathrm{kg}$ ) during first lactation from 7807 heifers with a second test-day SCC $\leq 50,000$ cells $/ \mathrm{mL}$, stratified by SCC in early lactation (SCCel, $\times 1000$ cells $/ \mathrm{mL}$ ), 0 to $50(\square), 51$ to $200(\mathbf{\square}), 201$ to $500(\triangle), 501$ to $1000(\Delta)$, and $>1000$ cells $/ \mathrm{mL}(\bigcirc)$.

teat canal colonizations and subclinical IMI due to CNS around calving will not become chronic (Myllys, 1995). However, duration of IMI varies among CNS species. Staphylococcus chromogenes, the most prevalent CNS before parturition, disappears from most quarters shortly after freshening, whereas Staphylococcus simulans persists into lactation (Aarestrup and Jensen, 1997). Intramammary infections caused by major mastitis pathogens will not cure as easily as IMI caused by CNS (Oliver and Mitchell, 1983; Roberson et al., 1994). For instance, 50\% of Staph. aureus IMI in heifers persist for at least $1 \mathrm{mo}$ (Roberson et al., 1994). In addition, the incidence rate of clinical mastitis in heifers is very high during the first $14 \mathrm{~d}$ of lactation (Barkema et al., 1998). Bacteriological culture results during early lactation were not available in our study. Rather, SCCel was used to reflect udder health of the heifers shortly after calving and to study the effect on future milk production. This approach allowed for a quantification of the impact based on a large number of animals.

An elevated SCCel shortly after calving was associated with lower test-day MY in the subsequent months. This is not surprising as mammary tissue of quarters infected with Staph. aureus is less developed and has greater leukocyte infiltration compared with uninfected quarters (Trinidad et al., 1990). Quarters infected with
CNS also exhibit greater leukocyte infiltration and a higher proportion of interalveolar stroma compared with uninfected controls. Furthermore, presence of IMI in unbred heifers increases leukocytosis in the mammary gland and reduces secretory activity in heifers, suggesting an adverse effect on future milk production (Trinidad et al., 1990). Our study showed that an elevated SCCel, reflecting the inflammation process of the mammary gland parenchyma caused by mastitis pathogens present at calving, has indeed a detrimental impact on the lactational milk production. Lower milk production is the consequence of the pathogenic effect of bacterial virulence factors and damage caused by PMNL and other inflammatory cells on the mammary parenchyma. Part of the negative effect of an increased SCCel on MY in this study was associated with elevation of subsequent test-day SCC. This was demonstrated by comparing models with and without LnSCC as a predictor variable: LnSCC, when incorporated into the models, took away part of the effect of LnSCCel. This was not unexpected, as, based on the same data set, we demonstrated earlier that heifers with elevated LnSCCel will on the average, have elevated test-day SCC later in lactation, and will have more test-day SCC $>200,000 \mathrm{cell} / \mathrm{mL}$, suggesting the presence of subclinical mastitis (De Vliegher et al., 2004a). 
Table 3. Regression coefficients for log-transformed SCC in early lactation (LnSCCel, $\times 1000$ cells $/ \mathrm{mL}$ ) per 30-d DIM interval based on the final multilevel linear regression models [with and without log-transformed test-day SCC $(\mathrm{LnSCC}, \times 1000$ cell $\mathrm{s} / \mathrm{mL})$ ] describing milk yield $(\mathrm{kg} / \mathrm{d})$ during first lactation (between 76 and 365 DIM) from 7807 dairy heifers from 2878 herds (sub dataset).

\begin{tabular}{|c|c|c|c|c|c|c|}
\hline \multirow[b]{2}{*}{ 30-d DIM interval } & \multicolumn{3}{|c|}{ Models with $\mathrm{LnSCC}^{1}$} & \multicolumn{3}{|c|}{ Models without LnSCC } \\
\hline & $\beta$ & $\mathrm{SE}$ & $P^{2}$ & $\beta$ & $\mathrm{SE}$ & $P^{2}$ \\
\hline 76 to 105 & -0.128 & 0.050 & $<0.001$ & -0.137 & 0.050 & $<0.001$ \\
\hline 106 to 135 & -0.100 & 0.050 & 0.008 & -0.113 & 0.050 & 0.004 \\
\hline 136 to 165 & -0.104 & 0.049 & 0.048 & -0.113 & 0.048 & 0.029 \\
\hline 166 to 195 & -0.048 & 0.050 & 0.019 & -0.056 & 0.050 & 0.014 \\
\hline 196 to 225 & -0.094 & 0.047 & 0.031 & -0.110 & 0.047 & 0.013 \\
\hline 226 to 255 & -0.097 & 0.046 & 0.059 & -0.110 & 0.046 & 0.028 \\
\hline 256 to 285 & -0.066 & 0.047 & NS & -0.079 & 0.047 & NS \\
\hline 286 to 315 & -0.121 & 0.052 & 0.022 & -0.141 & 0.051 & 0.007 \\
\hline 316 to 345 & -0.116 & 0.064 & NS & -0.135 & 0.064 & $\mathrm{NS}$ \\
\hline 346 to 365 & -0.050 & 0.107 & NS & -0.083 & 0.107 & NS \\
\hline
\end{tabular}

${ }^{1}$ Centered by subtracting the mean value (3.9). See text for details.

${ }^{2}$ Bonferroni corrected $P$ values (original values multiplied by 10 ), corresponding to test of both main effect and interaction.

Heifers with a first test-day SCC $<100,000$ cells/mL, produced approximately 400 and $750 \mathrm{~kg}$ more than heifers with a first test-day SCC of 100,000 to 400,000 and $>400,000$ cells $/ \mathrm{mL}$, respectively (Coffey et al., 1986). These differences were larger than in our study, but the comparison is difficult as, for instance, it was not clear when the first test-day SCC were recorded in that study. Furthermore, culling bias may have influenced our results because heifers with udder disorders at parturition are more likely to be culled during their first lactation (Waage et al., 2000). This has probably resulted in an overall underestimation of the effect of an elevated SCCel on MY throughout the first lactation and explains the smaller impact of LnSCCel on MY in the later 30-d DIM intervals.

Day of measurement of the first test-day SCC was not part of the evaluation by Coffey et al. (1986), although the statistically significant interaction between SCCel and DIM in our study indicates that it is important to take this into consideration. The biology behind this finding is associated with the decreasing SCCel between 5 and 14 DIM (Dohoo, 1993; Laevens et al., 1997; Barkema et al., 1999; De Vliegher et al., 2001), reflecting the declining prevalence of CNS-infected quarters in early lactation and an increasing MY (Schepers et al., 1997). In the previous study, the effect of SCCel on test-day SCC also depended on the day of assessment in early lactation (De Vliegher et al., 2004a). As mentioned earlier, a high proportion of the IMI caused by CNS is cleared once the heifer starts lactating because of their transient nature, but SCC in recovered quarters will take some time to return to a normal level. A heifer with an elevated SCCel at 5 DIM may have had quarters recovering from CNS infections, resulting in a more or less normal SCCel level within the next few days. Such a heifer will not produce much less milk than a heifer with a very low SCCel at 5 DIM. This hypothesis is supported by the findings from a study in which samples from 339 heifers were cultured in early lactation in a large dairy herd with a low prevalence of major mastitis pathogens. Intramammary infection caused by minor pathogens did not have a significant effect on milk production (Kirk et al., 1996). On the other hand, an SCCel that was still elevated 2 wk after calving had a larger impact on future milk production. Possibly, heifers with an elevated SCCel later in the early postpartum period suffered from a persistent IMI (e.g., caused by Staph. aureus), already present before calving, or had been infected early postpartum, resulting in elevated SCCel until 14 DIM and thereafter. The damaging effect of an Staph. aureus infection will be more extensive compared with a CNS IMI simply because Staph. aureus possesses a wider "arsenal" of virulence factors that allows this pathogen to cause more damage and, therefore, higher and extended SCC values. However, more studies are needed to elucidate these hypotheses and bacteriological cultures should be included.

The results from this study should motivate dairy farmers to try to reduce the number of heifers with an elevated SCCel. Farmers invest time and money in raising their young stock, but their heifers will not produce according to expectations if they freshen with an elevated SCCel. Therefore, farmers should focus on prevention of IMI before and at calving rather than on treatment of IMI after calving as the negative effect of an elevated SCCel on MY was still present, although smaller in size, in heifers with a second test-day SCC $\leq 50,000$ cell $/ \mathrm{mL}$. This means that even if a heifer has a low second test-day SCC it will, on average, be out- 
produced by a heifer with an equally low SCC at the second test-day but with a lower SCCel. Prevention of IMI prepartum in heifers remains difficult because our knowledge of the pathogenesis is still limited, even though some herd- and heifer-associated factors related to heifer mastitis have been identified (Fox et al., 1995; Myllys and Rautala, 1995; Østerås et al., 1997; Waage et al., 1998; Bareille et al., 2000; Waage et al., 2001; De Vliegher et al., 2004b).

Multilevel modeling can aid in estimating the relative importance of herd and individual factors with a view to targeting animal health interventions more effectively (McDermott and Schukken, 1994). Although management is key in mastitis prevention, focusing on differences between heifers rather than differences between herds is necessary to reduce the prevalence of heifers with an elevated SCCel as the vast majority of the variation in SCCel was present at the heifer level, leaving more room for improvement compared with the herd level (De Vliegher et al., 2004b). The findings for SCCel do not apply for MY because approximately $55 \%$ of the unexplained variation in MY was present at the herd level, indicating that farmers have more room to improve production in heifers by applying better management practices.

\section{CONCLUSIONS}

Elevated SCCel in heifers is associated with a decreased lactational production. The cumulative milk loss over the whole first lactation can be high: a heifer with an SCCel of 500,000 cells $/ \mathrm{mL}$ measured at 10 DIM, for instance, produced $119 \mathrm{~kg}$ less during first lactation than a heifer with an SCCel of 50,000 cells $/ \mathrm{mL}$ also measured at 10 DIM. The effect is, however, modified by the day of assessment of SCCel: an elevated SCCel at 5 DIM is less consequential than an equally high SCCel at 14 DIM. The suboptimal production could be partially explained by detrimental effects of IMI at calving on the secretory tissue but our study indicated that part of the effect was associated with permanently elevated SCC throughout lactation. The financial losses for a farm with a high prevalence of heifers with elevated SCCel can be large, resulting in suboptimal revenues.

\section{ACKNOWLEDGMENTS}

The authors would like to thank E. De Mûelenaere and the Flemish Cattle Breeding Association (Oosterzele, Belgium) for providing us with the milk-recording data and to Elanco Belgium for supporting this study financially.

\section{REFERENCES}

Aarestrup, F. M., and N. E. Jensen. 1997. Prevalence and duration of intramammary infection in Danish dairy heifers during the peripartum period. J. Dairy Sci. 80:307-312.

Bareille, N., H. Seegers, M. B. Kiebre-Toe, F. Beaudeau, and C. Fourichon. 2000. Risk factors for elevated milk somatic cell counts during early lactation in dairy heifers. Pages 509-514 in Proc. 10th Intern. Congr. Anim. Hyg., Maastricht, The Netherlands.

Barkema, H. W., H. Deluyker, Y. H. Schukken, and T. J. G. M. Lam. 1999. Quarter-milk somatic cell count at calving and at the first six milkings after calving. Prev. Vet. Med. 38:1-9.

Barkema, H. W., Y. H. Schukken, T. J. G. M. Lam, M. L. Beiboer, H. Wilmink, G. Benedictus, and A. Brand. 1998. Incidence of clinical mastitis in dairy herds grouped in three categories by bulk milk somatic cell counts. J. Dairy Sci. 81:411-419.

Bennedsgaard, T. W., C. Enevoldsen, S. M. Thamsborg, and M. Vaarst. 2003. Effect of mastitis treatment and somatic cell counts on milk yield in Danish organic dairy cows. J. Dairy Sci. 86:3174-3183.

Coffey, E. M., W. E. Vinson, and R. E. Pearson. 1986. Somatic cell counts and infection rates for cows of varying somatic cell count in initial test of first lactation. J. Dairy Sci. 69:552-555.

De Vliegher, S., H. W. Barkema, H. Stryhn, G. Opsomer, and A. de Kruif. 2004a. Impact of early lactation somatic cell count in heifers on somatic cell counts over the first lactation. J. Dairy Sci. 87:3672-3682.

De Vliegher, S., H. Laevens, G. Opsomer, E. De Mûelenaere, and A. de Kruif. 2001. Somatic cell counts in dairy heifers during early lactation. Flem. Vet. J. 70:212-215.

De Vliegher, S., H. Laevens, H. W. Barkema, I. Dohoo, H. Stryhn, G. Opsomer, and A. de Kruif. 2004b. Management practices and heifer characteristics associated with early lactation somatic cell count of Belgian dairy heifers. J. Dairy Sci. 87:937-947.

Dohoo, I. R. 1993. An evaluation of the validity of individual cow somatic cell counts from cows in early lactation. Prev. Vet. Med. 16:103-110.

Fox, L. K., S. T. Chester, J. W. Hallberg, S. C. Nickerson, J. W. Pankey, and L. D. Weaver. 1995. Survey of intramammary infections in dairy heifers at breeding age and first parturition. J. Dairy Sci. 78:1619-1628.

Hortet, P., F. Beaudeau, H. Seegers, and C. Fourichon. 1999. Reduction in milk yield associated with somatic cell counts up to 600,0000 cells $/ \mathrm{mL}$ in French Holstein cows without clinical mastitis. Prev. Vet. Med. 61:33-42.

Kirk, J. H., J. C. Wright, S. L. Berry, J. P. Reynolds, J. P. Maas, and A. Ahmadi. 1996. Relationship of milk culture status at calving with somatic cell counts and milk production of dairy heifers during early lactation on a Californian dairy. Prev. Vet. Med. 28:187-198.

Koldeweij, E., U. Emanuelson, and L. Janson. 1999. Relation of milk production loss to milk somatic cell count. Acta Vet. Scand. 40:47-56.

Laevens, H., H. Deluyker, Y. H. Schukken, L. De Meulemeester, R. Vandermeersch, E. De Mûelenaere, and A. de Kruif. 1997. Influence of parity and stage of lactation on the somatic cell count in bacteriologically negative cows. J. Dairy Sci. 80:3219-3226.

Matthews, K. R., R. J. Harmon, and B. E. Langlois. 1992. Prevalence of Staphylococcus species during the periparturient period in primiparous and multiparous cows. J. Dairy Sci. 75:1835-1839.

McDermott, J. J., and Y. H. Schukken. 1994. A review of methods used to adjust for cluster effects in explanatory epidemiological studies of animal populations. Prev. Vet. Med. 18:155-173.

Myllys, V. 1995. Staphylococci in heifer mastitis before and after parturition. J. Dairy Res. 62:51-60.

Myllys, V., and H. Rautala. 1995. Characterization of clinical mastitis in primiparous heifers. J. Dairy Sci. 78:538-545.

Oliver, S. P., and B. M. Jayarao. 1997. Coagulase-negative staphylococcal intramammary infections in cows and heifers during the nonlactating and periparturient periods. J. Vet. Med. B. $44: 355-363$ 
Oliver, S. P., M. J. Lewis, B. E. Gillespie, and H. H. Dowlen. 1992. Influence of prepartum antibiotic therapy on intramammary infections in primigravid heifers during early lactation. J. Dairy Sci. 75:406-414.

Oliver, S. P., M. J. Lewis, B. E. Gillespie, H. H. Dowlen, E. C. Jaenicke, and R. K. Roberts. 2003. Prepartum antibiotic treatment of heifers: Milk production, milk quality and economic benefit. J. Dairy Sci. 86:1187-1193.

Oliver, S. P., and B. A. Mitchell. 1983. Intramammary infections in primigravid heifers near parturition. J. Dairy Sci. 83:1180-1183.

Østerås, O., R. B. Larssen, and E. Simensen. 1997. Environmental risk factors associated with mastitis in heifers. Pages 40-43 in Proc. 9th Intl. Congr. Anim. Hyg., Helsinki, Finland.

Pankey, J. W., P. A. Drechsler, and E. E. Wildman. 1991. Mastitis prevalence in primigravid heifers at parturition. J. Dairy Sci. 74:1550-1552.

Rasbash, J., W. Browne, H. Goldstein, M. Yang, I. Plewis, M. Healy, G. Woodhouse, D. Draper, I. Langford, and T. Lewis. 2000. A user's guide to MlwiN. 2nd ed. Institute of Education, London, UK.

Roberson, J. R., L. K. Fox, D. D. Hancock, and C. C. Gay. 1994. Coagulase-positive Staphylococcus intramammary infections in dairy heifers. J. Dairy Sci. 77:958-969.
Rupp, R., and D. Boichard. 2000. Relationship of early first lactation somatic cell count with risk of subsequent first clinical mastitis. Livest. Prod. Sci. 62:169-180.

Schepers, A. J., T. J. G. M. Lam, Y. H. Schukken, J. B. M. Wilmink, and W. J. A. Hanekamp. 1997. Estimation of variance components for somatic cell counts to determine thresholds for uninfected quarters. J. Dairy Sci. 80:1833-1840.

Snijders, T. A. B., and R. J. Bosker. 1999. Multilevel Analysis: An Introduction to Basic and Advanced Multilevel Modeling. Sage Publications, London, UK.

Trinidad, P., S. C. Nickerson, and R. W. Adkinson. 1990. Histopathology of staphylococcal mastitis in unbred dairy heifers. J. Dairy Sci. 73:639-647.

Waage, S., S. A. Ødegaard, A. Lund, S. Brattgjerd, and T. Rothe. 2001. Case-control study of risk factors for clinical mastitis in postpartum dairy heifers. J. Dairy Sci. 84:392-399.

Waage, S., H. R. Skei, J. Rise, T. Rogdo, S. Sviland, and S. A. Ødegaard. 2000. Outcome of clinical mastitis in dairy heifers assessed by reexamination of cases one month after treatment. J. Dairy Sci. 83:70-76.

Waage, S., S. Sviland, and S. A. Ødegaard. 1998. Identification of risk factors for clinical mastitis in dairy heifers. J. Dairy Sci. $81: 1275-1284$. 